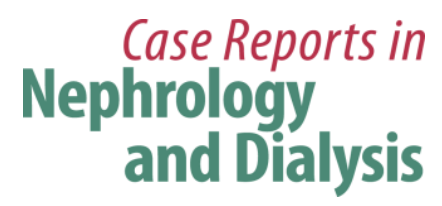

Case Rep Nephrol Dial 2017;7:13-17

DOI: $10.1159 / 000455828$

Published online: January 20, 2017

\title{
Tubular Dysfunction Mimicking Dent's Disease in 2 Infants Born with Extremely Low Birth Weight
}

\author{
Midori Awazu ${ }^{a}$ Mie Arai ${ }^{b}$ Shoko Ohashic Hirotaka Takahashi ${ }^{b}$ \\ Takashi Sekine $^{d}$ Kazushige Ikeda ${ }^{a}$ \\ ${ }^{a}$ Department of Pediatrics, Keio University School of Medicine, Tokyo, Japan; ${ }^{b}$ Department \\ of Pediatrics, Tokyo Metropolitan Ohtsuka Hospital, Tokyo, Japan; ' Department of \\ Neonatology, Tokyo Metropolitan Ohtsuka Hospital, Tokyo, Japan; ${ }^{\mathrm{d} D e p a r t m e n t}$ of \\ Pediatrics, Ohashi Hospital, Toho University School of Medicine, Tokyo, Japan
}

\section{Keywords}

Fanconi syndrome $\cdot$ Low birth weight $\cdot$ Preterm infants $\cdot$ Proximal tubule

\begin{abstract}
Two preterm infants, with extremely low birth weight born at gestational weeks 24 and 25 , showed generalized proximal tubular dysfunction during their stay in the neonatal intensive care unit, including glucosuria, low molecular weight proteinuria, phosphaturia, uricosuria, enzymuria (elevated urine $\mathrm{N}$-acetyl- $\beta$-D-glucosaminidase), panaminoaciduria, and hypercalciuria, associated with renal calcification. Renal tubular acidosis was not present in either patient. DNA mutation analysis for Dent's disease, performed in patient 1 , was negative. Although both patients had rickets of prematurity, tubular dysfunction persisted after its resolution. Patient 2, who had severe chronic lung disease, also had elevated serum creatinine, proteinuria, and hypertension, suggesting glomerular damage. In patient 1 , low molecular weight proteinuria, enzymuria, panaminoaciduria, hypercalciuria, and renal calcification were still present at the age of 8 years. In patient 2 , tubular dysfunction resolved except for $\beta 2$ microglobulinuria at the age of 5 years. While a reduced nephron number resulting in focal segmental glomerulosclerosis is well-known, generalized proximal tubular dysfunction can also occur in infants born preterm and/or with extremely low birth weight.
\end{abstract}




\section{Case Reports in Nephrology and Dialysis}

\section{Introduction}

Nephrogenesis continues up to 34-36 weeks of gestation in humans. Low birth weight infants due to intrauterine growth restriction or preterm birth are known to have a low nephron number [1]. A low nephron number leads to hyperfiltration and hypertrophy of the remaining nephrons resulting in glomerulosclerosis [2]. Although many studies investigated glomerular function in subjects born at low birth weight [3], little attention has been paid to tubular function. We report 2 preterm infants born at extremely low birth weight who presented with generalized tubular dysfunction mimicking Dent's disease, a form of Fanconi syndrome characterized by proximal tubular dysfunction, hypercalciuria, nephrolithiasis, and nephrocalcinosis.

\section{Case Presentation}

\section{Patient 1}

Patient 1 was born at the gestational age of 25 weeks by premature labor. Her weight was $741 \mathrm{~g}$ (90th percentile), Apgar was 1 at $1 \mathrm{~min}$ and 5 at $5 \mathrm{~min}$. The neonatal period was complicated by acute respiratory distress, patent ductus arteriosus that was closed with indomethacin, anemia, retinopathy of prematurity, rickets, and chronic lung disease. During her stay in the neonatal intensive care unit, urine protein was found to be up to $3+$, blood up to $1+$, glucose up to $1+$, the calcium to creatinine ratio $0.56-1.0 \mathrm{~g} / \mathrm{g}, \beta 2$ microglobulin 299$27,950 \mu \mathrm{g} / \mathrm{L}$, the N-acetyl- $\beta$-D-glucosaminidase (NAG) to creatinine ratio $34.6 \mathrm{U} / \mathrm{g}(<5)$, the microalbumin to creatinine ratio $29.6 \mathrm{mg} / \mathrm{g}$, and percent tubular reabsorption of phosphate 94\%. Panaminoaciduria was also present. Serum creatinine was $0.2 \mathrm{mg} / \mathrm{dL}$, urea nitrogen $8.0 \mathrm{mg} / \mathrm{dL}$, sodium $137.7 \mathrm{mEq} / \mathrm{L}$, potassium $4.3 \mathrm{mEq} / \mathrm{L}$, chloride $100 \mathrm{mEq} / \mathrm{L}$, bicarbonate $25.8 \mathrm{mEq} / \mathrm{L}$, calcium $10 \mathrm{mg} / \mathrm{dL}$, phosphorus $6.6 \mathrm{mg} / \mathrm{dL}$, uric acid $1.1 \mathrm{mg} / \mathrm{dL}$, and normal glucose. Echosonography of the kidney showed bilateral calcification and renal stones. She had no history of furosemide use. Metaphyseal cupping was noted and vitamin D supplementation was started. Tubular dysfunction persisted after the completion of treatment. Mutation analysis for CLCN5 and OCRL1 by direct sequencing was negative. At the age of 9 years, serum uric acid was $2.0 \mathrm{mg} / \mathrm{dL}$ with serum creatinine of $0.29 \mathrm{mg} / \mathrm{dL}$. Urinalysis was normal. The urine calcium to creatinine ratio was $0.30 \mathrm{~g} / \mathrm{g}, \beta 2$ microglobulin $281 \mu \mathrm{g} / \mathrm{L}$, the NAG to creatinine ratio $4.2 \mathrm{U} / \mathrm{g}$, the microalbumin to creatinine ratio $16.4 \mathrm{mg} / \mathrm{g}$, and panaminoaciduria was resolved. Bilateral renal stones and calcification were still present.

\section{Patient 2}

Patient 2 was born at the gestational age of 24 weeks by cesarean section for maternal hypertension. Birth weight was $335 \mathrm{~g}$ ( $<10$ th percentile), and Apgar was 2 at $1 \mathrm{~min}$ and 4 at $5 \mathrm{~min}$. His course was complicated by acute respiratory distress, rickets, and chronic lung disease. At the age of 4 months, right renal calcification was noted by echosonography. He had no history of furosemide use. Serum creatinine was $0.4 \mathrm{mg} / \mathrm{dL}$, urea nitrogen $3.9 \mathrm{mg} / \mathrm{dL}$, sodium $137 \mathrm{mEq} / \mathrm{L}$, potassium $3.4 \mathrm{mEq} / \mathrm{L}$, chloride $103 \mathrm{mEq} / \mathrm{L}$, bicarbonate $25.8 \mathrm{mEq} / \mathrm{L}$, calcium $9.3 \mathrm{mg} / \mathrm{dL}$, phosphorus $3.4 \mathrm{mg} / \mathrm{dL}$, and uric acid $5.1 \mathrm{mg} / \mathrm{dL}$. Urinalysis showed protein $1+$, blood -, glucose $2+$, protein to creatinine ratio $1.92 \mathrm{~g} / \mathrm{g}$, calcium to creatinine ratio up to $0.5 \mathrm{~g} / \mathrm{g}, \beta 2$ microglobulin $65,500 \mu \mathrm{g} / \mathrm{L}, \mathrm{NAG}$ to creatinine ratio $96.0 \mathrm{U} / \mathrm{g}$, and percent tubular reabsorption of phosphate $64 \%$. At the age of 2.5 years, his blood pressure was 124/88 mm Hg. Serum creatinine was $0.4 \mathrm{mg} / \mathrm{dL}$, urea nitrogen $20.8 \mathrm{mg} / \mathrm{dL}$, uric acid 4.7 


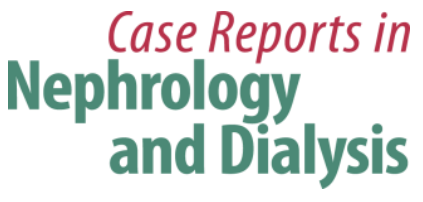

Case Rep Nephrol Dial 2017;7:13-17

DOI: $10.1159 / 000455828$

(c) 2017 The Author(s). Published by S. Karger AG, Basel www.karger.com/cnd

Awazu et al.: Tubular Dysfunction Mimicking Dent's Disease in 2 Infants Born with Extremely Low Birth Weight

$\mathrm{mg} / \mathrm{dL}$ with normal electrolytes and bicarbonate. Urinalysis showed protein 1+, blood-, glucose -, with no cells or casts. The urine protein to creatinine ratio was $0.11 \mathrm{~g} / \mathrm{g}$, calcium to creatinine ratio $0.17 \mathrm{~g} / \mathrm{g}$, percent tubular reabsorption of phosphorus $93 \%, \beta 2$ microglobulin $8,410 \mu \mathrm{g} / \mathrm{L}$, the NAG to creatinine ratio $11.8 \mathrm{U} / \mathrm{g}$, and the microalbumin to creatinine ratio $34.1 \mathrm{mg} / \mathrm{g}$. Panaminoaciduria was noted, and calcification of the right kidney was still present. Because of hypertension and proteinuria, salt intake was restricted to $3 \mathrm{~g}$ per day and losartan was initiated. Blood pressure and the urine microalbumin to creatinine ratio fell to $81 / 57 \mathrm{~mm} \mathrm{Hg}$ and $16.7 \mathrm{mg} / \mathrm{g}$, respectively. At the age of 5 years, serum creatinine was $0.5 \mathrm{mg} / \mathrm{dL}$ and uric acid $5.2 \mathrm{mg} / \mathrm{dL}$. The urine protein to creatinine ratio was $0.14 \mathrm{~g} / \mathrm{g}$, the calcium to creatinine ratio $0.06 \mathrm{~g} / \mathrm{g}, \beta 2$ microglobulin $298 \mu \mathrm{g} / \mathrm{L}$, and the NAG to creatinine ratio $2.4 \mathrm{U} / \mathrm{g}$. Echosonography revealed increased echogenicity and small kidneys (right 52 $\mathrm{mm}$, left $45 \mathrm{~mm}$ ) but no obvious calcification.

Both patients did not have symptoms or laboratory abnormalities suggesting glycogen storage disease, Lowe syndrome, Wilson disease, tyrosinemia, and other diseases characterized by Fanconi syndrome.

\section{Discussion}

We report 2 patients who were born preterm at extremely low birth weight and had proximal tubular dysfunction along with renal calcification. One patient also had elevated serum creatinine and proteinuria suggesting glomerular damage. Subjects with low birth weight are known to have a low nephron number, a decreased glomerular filtration rate, and proteinuria or albuminuria resulting in focal segmental glomerulosclerosis [3, 4]. As for tubular function in low birth weight infants, increased calcium and phosphorus excretion has been reported [5]. Our patients also had glucosuria, low molecular weight proteinuria, enzymuria, uricosuria, and panaminoaciduria. Renal calcification along with these tubular abnormalities is the characteristic of Dent's disease, a form of Fanconi syndrome. Approximately $84 \%$ of Dent's disease is caused by mutations of the chloride channel CLCN5 or OCRL1, the causative gene for Lowe syndrome [6]. Patient 1 was examined for the mutation of these genes, which turned out to be negative. Although the possibility remains that patient 1 has yet an unidentified gene mutation for Dent's disease, her laboratory findings mostly improved except for hypercalciuria and renal calcification. Patient 2 did not undergo gene analysis. Recent evidence suggests that Dent's disease presents with nephrotic syndrome and focal glomerulosclerosis [7]. The reported patients, however, were much older than patient 2 and not preterm suggesting that the low glomerular filtration in patient 2 was due to preterm and or low birth weight.

Both patients had rickets during the neonatal period, which could be the cause of the tubular dysfunction [8]. However, the tubular dysfunction persisted after the treatment of rickets. It is noteworthy that the tubular dysfunction partially resolved as the patients grew older which may suggest delayed maturation. Therefore, the tubular abnormality is most likely secondary to extreme low birth weight and/or prematurity, although the possibility remains that some unknown gene mutation may be the cause of a Dent-like phenotype in patient 1 .

Urine $\beta 2$ microglobulin and NAG are known to be elevated in the neonatal period, especially in preterm infants [9]. This is thought to be due to proximal tubule immaturity. Systemic hypoxia or kidney hypoperfusion seems to aggravate the dysfunction [9]. The causative factor of proximal tubule dysfunction is thus something influenced by oxygen availabil- 
ity. Mitochondrial function, important in ATP production, and Na-K-ATPase activity, a driving force in the reabsorption, can be altered by oxygen availability, and are reported to be immature in neonates, especially in preterm neonates $[10,11]$. Inhibition of mitochondrial function or Na-K-ATPase is known to cause Fanconi syndrome [12]. Of interest, in the offspring of low-protein diet-fed rats, a model of low birth weight, urine sodium, and calcium excretion were reported to be increased along with reduced Na-K-ATPase activity [13].

Nephrocalcinosis is known to occur in preterm or low-birth weight infants [14]. Risk factors for developing nephrocalcinosis besides prematurity or low birth weight are acidosis, calciuria, phosphaturia, hypocituria, and furosemide use $[9,15]$. Of interest, 1 study reported increased urine NAG in infants with nephrocalcinosis raising a possibility that other tubular dysfunction such as low molecular weight proteinuria, glucosuria, and panaminoaciduria may also be present if investigated [16]. Spontaneous resolution of nephrocalcinosis is reported to occur in $75-90 \%$ patients around the age of 7 years [17]. In patient 2, nephrocalcinosis resolved by the age of 5 years but the kidney size was small. It is reported that the renal length was reduced even after 20 years in subjects with very preterm birth [18].

We have reported generalized proximal tubular dysfunction in 2 preterm patients with extreme low birth weight. These patients may be extreme examples, but tubular dysfunction may not be uncommon in extreme low birth weight infants. In our preliminary study examining the tubular function in subjects born with extremely low birth weight, as much as $90 \%$ had at least 1 proximal tubular dysfunction, such as calciuria, low molecular weight proteinuria, enzymuria, glucosuria, or uricosuria. Attention should be paid to tubules as well as glomeruli in subjects born preterm or at low birth weight.

\section{Statement of Ethics}

The authors have no ethical conflicts to disclose.

\section{Disclosure Statement}

The authors have no conflicts of interest to disclose.

\section{References}

1 Merlet-Benichou C, Gilbert T, Vilar J, Moreau E, Freund N, Lelievre-Pegorier M: Nephron number: variability is the rule. Causes and consequences. Lab Invest 1999;79:515-527.

2 Brenner BM: Nephron adaptation to renal injury or ablation. Am J Physiol 1985;249:F324-F337.

-3 White SL, Perkovic V, Cass A, Chang CL, Poulter NR, Spector T, Haysom L, Craig JC, Salmi IA, Chadban SJ, Huxley RR: Is low birth weight an antecedent of CKD in later life? A systematic review of observational studies. Am J Kidney Dis 2009;54:248-261.

-4 Hodgin JB, Rasoulpour M, Markowitz GS, D’Agati VD: Very low birth weight is a risk factor for secondary focal segmental glomerulosclerosis. Clin J Am Soc Nephrol 2009;4:71-76.

-5 Rodriguez-Soriano J, Aguirre M, Oliveros R, Vallo A: Long-term renal follow-up of extremely low birth weight infants. Pediatr Nephrol 2005;20:579-584.

-6 Sekine T, Komoda F, Miura K, Takita J, Shimadzu M, Matsuyama T, Ashida A, Igarashi T: Japanese Dent disease has a wider clinical spectrum than Dent disease in Europe/USA: genetic and clinical studies of 86 unrelated patients with low-molecular-weight proteinuria. Nephrol Dial Transplant 2014;29:376384 . 


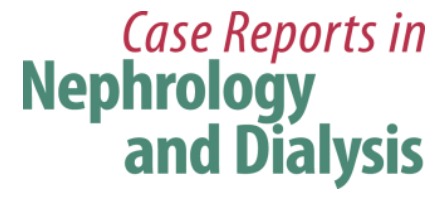

Case Rep Nephrol Dial 2017;7:13-17 DOI: $10.1159 / 000455828$ C 2017 The Author(s). Published by S. Karger AG, Basel www.karger.com/cnd

Awazu et al.: Tubular Dysfunction Mimicking Dent's Disease in 2 Infants Born with Extremely Low Birth Weight

7 Frishberg Y, Dinour D, Belostotsky R, Becker-Cohen R, Rinat C, Feinstein S, Navon-Elkan P, Ben-Shalom E: Dent's disease manifesting as focal glomerulosclerosis: is it the tip of the iceberg? Pediatr Nephrol 2009;24:2369-2373.

8 Scriver CR: Rickets and the pathogenesis of impaired tubular transport of phosphate and other solutes. Am J Med 1974;57:43-49.

-9 Tsukahara H, Yoshimoto M, Saito M, Sakaguchi T, Mitsuyoshi I, Hayashi S, Nakamura K, Kikuchi K, Sudo M: Assessment of tubular function in neonates using urinary beta 2-microglobulin. Pediatr Nephrol 1990;4:512-514.

-10 Prieur B, Cordeau-Lossouarn L, Rotig A, Bismuth J, Geloso JP, Delaval E: Perinatal maturation of rat kidney mitochondria. Biochem J 1995;305(Pt 2):675-680.

-11 Holtback U, Aperia AC: Molecular determinants of sodium and water balance during early human development. Semin Neonatol 2003;8:291-299.

12 Sirac C, Bridoux F, Essig M, Devuyst O, Touchard G, Cogne M: Toward understanding renal Fanconi syndrome: step by step advances through experimental models. Contrib Nephrol 2011;169:247-261.

13 Ashton N, Al-Wasil SH, Bond H, Berry JL, Denton J, Freemont AJ: The effect of a low-protein diet in pregnancy on offspring renal calcium handling. Am J Physiol Regul Integr Comp Physiol 2007;293:R759-R765.

14 Hein G, Richter D, Manz F, Weitzel D, Kalhoff H: Development of nephrocalcinosis in very low birth weight infants. Pediatr Nephrol 2004;19:616-620.

15 Habbig S, Beck BB, Hoppe B: Nephrocalcinosis and urolithiasis in children. Kidney Int 2011;80:12781291.

$\checkmark 16$ Sheu JN, Chen CH, Lue KH, Chen JY, Tsau YK, Chen JH: Renal calcification in very low birth weight infants. Am J Nephrol 1993;13:6-11.

-17 Kim JJ, Amin S: QUESTION 2. Does nephrocalcinosis in ex-premature babies cause long-term renal problems? Arch Dis Child 2009;94:991-992.

-18 Keijzer-Veen MG, Devos AS, Meradji M, Dekker FW, Nauta J, van der Heijden BJ: Reduced renal length and volume 20 years after very preterm birth. Pediatr Nephrol 2010;25:499-507. 